\title{
Assessment of oral cleanliness and gingival condition among intermediate Thamarian school students
}

Faraed D Salman BDS, MSc (Lect)

\author{
Dept of Pedod, Orthod and Prev Dent \\ College of Dentistry, University of Mosul
}

\begin{abstract}
Aims: To evaluate the oral cleanliness and gingival health among intermediate school students and to find if there was any variation between age and sex groups in Thamar-Yemen. Material and Methods: A sample of 596 students aged 13-15 years old (308 males, 288 females) were examined using plaque index score by Silness and Löe (1964) and gingival index by Löe and Silness (1963). The clinical examinations were carried out in the school using plane mouth mirrors, WHO periodontal probes to detect the dental plaque and gingival health. Results: The mean plaque score for the total sample was 0.90 . The plaque index was increasing with age, females reported less mean plaque scores than males with statistically significant difference between them. The mean gingival score was 0.52 for the total sample and it was increasing with age with statistical significant difference. Females also reported less gingival scores than males with statistical significant difference between them. The study revealed that $45.1 \%$ of the total sample did not brush their teeth. Conclusion: Gingival and periodontal diseases are indirectly related to the exposure of bacterial plaque for long time which calls for integrated, coordinated planning of preventive and treatment services as an urgent priority.

Key Words: Oral cleanliness, plaque index, gingival index, intermediate school students.
\end{abstract}

Salman FD. Assessment of oral cleanliness and gingival condition among intermediate Thamarian school students. Al-Rafidain Dent J. 2006; 6(2): 181-185.

Received: 18/12/2005 Sent to Referees: 19/12/2005

Accepted for Publication: 12/2/2006

\section{INTRODUCTION}

Gingival inflammation is present in most communities, ${ }^{(1)}$ and it is universal in young people ${ }^{(2)}$ and widespread in children. $^{(3)}$ The prevalence of gingivitis increases with increasing age, beginning in deciduous dentition and reaching a peak at puberty. ${ }^{(4)}$ The time of puberty is between $12-$ 15 years old. During this time, progression of periodontal breakdown may be observed. ${ }^{(5)}$

The association may be a reflection of the aging progress per se, but it is more likely an indirect reflection of the length of time the periodontal structures have been exposed to bacterial plaque. ${ }^{(6)}$

The lack of resources from which this country suffers underlines the necessity for a careful planning of oral health services and emphasizes the need for prevention and control rather than a curative and rehabilitative approach. ${ }^{(7,8)}$

The trend for this disease in this developing country calls for integrated, coordinated planning of preventive and treatment services for oral health services as an urgent priority. ${ }^{(9)}$

The aims of this study were to evaluate the oral cleanliness and gingival health among intermediate school students and to find if there was any variation between age and sex groups in Thamar-Yemen.

\section{MATERIAL AND METHODS}

This study was conducted in ThamarYemen during the period between October 2001-January 2002.

The sample of the study was composed of 596 intermediate school students ages $13-15$ years old ( 308 males and 288 females) selected randomly from four intermediate schools ( 2 for boys and 2 for gir1s). The sample was divided into 3 age groups; namely, 13, 14, 15 years old, which represents the first, second and the last year of intermediate schooling. Each student was asked about frequency of tooth brushing by direct contact whether infrequent, once, twice or more. Clinical examinations were carried out in the school under 
adequate daylight. Each student was sit in upright position in front of the examiner and examination was done using plane mouth mirrors, WHO periodontal probes to detect the dental plaque and gingival health and $0.2 \%$ Septicin for sterilization of instruments.

The indices used for assessment of gingival and periodontal conditions were as follow:

1) Plaque index by Silness and Lö $e^{(10)}$ to evaluate the oral hygiene of the students:

Score 0: No plaque in gingival area.

Score 1: A film of plaque adherent to the gingival margin and the adjacent area of the tooth. The plaque may only be recognized by running a probe a cross the tooth surface.

Score 2: A moderate accumulation of soft deposit within the gingival pocket on the tooth and gingival margin. This can be recognized with the naked eye.

Score 3: A heavy accumulation of plaque within gingival pocket or on the tooth and gingival margin.

2) Gingival index by Löe and Silness ${ }^{(11)}$ to evaluate the gingival health of the students:

Score 0: Normal gingiva.

Score 1: Mild inflammation: This includes slight change in colour, slight oedema, no bleeding on probing.

Score 2: Moderate inflammation: Redness, oedema, bleeding of the gum on probing.

Score 3: Severe inflammation: Marked redness, oedema, ulceration and there is a tendency for spontaneous bleeding.
The statistical analysis of the data included the mean and standard error for plaque and gingival indices using one way analysis of variance (ANOVA) and Duncan's Multiple Range Test. Comparing between total males and females was done using F-ratio test. Differences were tested for their significancy for plaque index and gingival index at $p \leq 0.01$ level.

\section{RESULTS}

There were 596 intermediate school students comprising $51.67 \%$ males and $48.33 \%$ females. The population sample was divided into 3 age groups (Table 1). The number and percentage of children according to the frequency of tooth brushing were shown in Table (2). The study indicated that $45.1 \%$ of the sample did not brush their teeth. Females reported more frequently brush their teeth $(33 \%)$ than males. Also the older age groups (14 and 15 years old) more frequently brushed their teeth (30\% and $41 \%$, respectively) than younger age group (28.7\%).

Table (3) showed plaque index scores according to sex and age groups. The mean plaque for the total sample was 0.9 and males reported higher mean than females in all age groups and the total males also higher than total females with statistical significant difference at $p \leq 0.01$.

The study showed that the mean plaque increased with significant difference between 13 and 14 and between 13 and 15 years old.

Table (4) showed the mean gingival score index according to sex and age groups. The mean for the total sample was 0.52 . Males reported higher mean gingival score than females. This difference was found to be significant at $p \leq 0.01$.

Table (1): Number and percentage of individuals distributed according to sex and age groups

\begin{tabular}{ccccccc}
\hline \multirow{2}{*}{$\begin{array}{c}\text { Age Groups } \\
\text { (Years) }\end{array}$} & \multicolumn{2}{c}{ Male } & \multicolumn{2}{c}{ Female } & \multicolumn{2}{c}{ Total } \\
\cline { 2 - 7 } & No. & \% & No. & \% & No. & \% \\
\hline $\mathbf{1 3}$ & 100 & 32.46 & 108 & 51.92 & 208 & 34.89 \\
$\mathbf{1 4}$ & 108 & 54.54 & 90 & 45.45 & 198 & 33.22 \\
$\mathbf{1 5}$ & 100 & 52.63 & 90 & 47.36 & 190 & 31.87 \\
\hline Total & 308 & 51.67 & 288 & 48.33 & 596 & 100 \\
\hline
\end{tabular}


Table (2): Frequency and percentage distribution of individuals according to tooth brushing by sex and age groups

\begin{tabular}{cccccccccc}
\hline \multirow{2}{*}{ Age Groups (Years) } & \multicolumn{2}{c}{$\mathbf{1 3}$} & \multicolumn{3}{c}{$\mathbf{1 4}$} & \multicolumn{3}{c}{$\mathbf{1 5}$} & \multicolumn{2}{c}{ Total } \\
\cline { 3 - 10 } & No. & $\mathbf{\%}$ & No. & \% & No. & \% & No. & \% \\
\hline \multirow{4}{*}{ Male } & Never & 62 & 62.0 & 64 & 59.3 & 71 & 71.0 & 197 & 64.0 \\
& Infrequent & 19 & 19.0 & 28 & 25.9 & 17 & 17.0 & 64 & 20.8 \\
& Once & 13 & 13.0 & 7 & 6.5 & 3 & 3.0 & 23 & 7.5 \\
& Twice or more & 6 & 6.0 & 9 & 8.3 & 4 & 9.0 & 19 & 7.8 \\
\hline \multirow{4}{*}{ Female } & Never & 38 & 35.2 & 19 & 21.1 & 15 & 16.7 & 72 & 25.0 \\
& Infrequent & 39 & 36.1 & 44 & 48.9 & 38 & 42.2 & 121 & 42.0 \\
& Once & 22 & 20.4 & 11 & 12.2 & 17 & 18.9 & 50 & 17.4 \\
& Twice or more & 9 & 8.3 & 16 & 17.8 & 20 & 22.2 & 45 & 15.6 \\
\hline \multirow{4}{*}{ Total } & Never & 100 & 48.0 & 83 & 41.9 & 86 & 46.4 & 269 & 45.1 \\
& Infrequent & 58 & 27.8 & 72 & 36.3 & 55 & 26.7 & 158 & 31.0 \\
& Once & 35 & 16.8 & 18 & 9 & 20 & 10.8 & 73 & 12.2 \\
& Twice or more & 15 & 7.2 & 25 & 12.6 & 24 & 12.9 & 69 & 11.5 \\
\hline
\end{tabular}

Table (3): Analysis of variance and Duncan's Multiple Range Test of plaque index according to sex and age groups

\begin{tabular}{|c|c|c|c|c|c|}
\hline Source & df & $\begin{array}{l}\begin{array}{l}\text { Sum of } \\
\text { square }\end{array} \\
\end{array}$ & $\begin{array}{c}\text { Mean } \\
\text { Square } \\
\end{array}$ & F-value & $p$-value \\
\hline Between Groups & 2 & 0.852 & 0.426 & & \\
\hline Within Groups & 285 & 37.367 & 0.131 & 3.249 & 0.040 \\
\hline Total & 287 & 38.219 & & & \\
\hline \multirow{2}{*}{$\begin{array}{l}\text { Age Groups } \\
\text { (Years) }\end{array}$} & \multicolumn{5}{|c|}{ Mean + SE } \\
\hline & \multicolumn{2}{|c|}{ Male } & Female & \multicolumn{2}{|c|}{ Total } \\
\hline 13 & \multicolumn{2}{|c|}{$0.96 \pm 0.04 \mathrm{a}$} & $0.70 \pm 0.03 \mathrm{a}$ & \multicolumn{2}{|c|}{$0.83 \pm 0.02 \mathrm{a}$} \\
\hline 14 & \multirow{2}{*}{\multicolumn{2}{|c|}{$0.99 \pm 0.03 \mathrm{a}$}} & $0.83 \pm 0.04 \mathrm{~b}$ & \multicolumn{2}{|c|}{$0.92 \pm 0.03 \mathrm{~b}$} \\
\hline 15 & & $1.11 \pm 0.04 \mathrm{~b}$ & $0.79 \pm 0.05 \mathrm{ab}$ & \multicolumn{2}{|c|}{$0.96 \pm 0.03 \mathrm{~b}$} \\
\hline Total & \multicolumn{2}{|c|}{$1.02+0.02 *$} & $0.77 \pm 0.02$ & \multicolumn{2}{|c|}{$0.90+0.02$} \\
\hline
\end{tabular}

Table (4): Analysis of variance and Duncan's Multiple Range Test of gingival index according to sex and age groups

\begin{tabular}{|c|c|c|c|c|c|}
\hline Source & df & $\begin{array}{l}\text { Sum of } \\
\text { Square }\end{array}$ & $\begin{array}{c}\text { Mean } \\
\text { Square }\end{array}$ & F-value & $p$-value \\
\hline Between Groups & 2 & 1.889 & 0.944 & & \\
\hline Within Groups & 285 & 40.006 & 140 & 6.728 & 0.001 \\
\hline Total & 287 & 41.895 & & & \\
\hline \multirow{2}{*}{$\begin{array}{l}\text { Age Groups } \\
\text { (Years) }\end{array}$} & \multicolumn{5}{|c|}{ Mean + SE } \\
\hline & \multicolumn{2}{|c|}{ Male } & Female & \multicolumn{2}{|c|}{ Total } \\
\hline 13 & \multicolumn{2}{|c|}{$0.55 \pm 0.04 \mathrm{a}$} & $0.38 \pm 0.03 \mathrm{a}$ & \multicolumn{2}{|c|}{$0.46+0.02 \mathrm{a}$} \\
\hline 14 & \multicolumn{2}{|c|}{$0.53 \pm 0.03 \mathrm{a}$} & $0.54 \pm 0.04 \mathrm{~b}$ & \multicolumn{2}{|c|}{$0.53 \pm 0.03 \mathrm{ab}$} \\
\hline 15 & \multicolumn{2}{|c|}{$0.60 \pm 0.03 \mathrm{a}$} & $0.55 \pm 0.05 \mathrm{~b}$ & \multicolumn{2}{|c|}{$0.57 \pm 0.03 \mathrm{~b}$} \\
\hline Total & \multicolumn{2}{|c|}{$0.56 \pm 0.02$} & $0.48 \pm 0.02$ & \multicolumn{2}{|c|}{$0.52+0.02$} \\
\hline
\end{tabular}




\section{DISCUSSION}

Tooth brushing data indicated that about $45.1 \%$ of the total sample did not brush their teeth. The percentage of subjects brushed their teeth is less than other studies carried out in developing and developed countries; ${ }^{(11-15)}$ where in Iraq (Mosul), it was $60 \%{ }^{(12)}$ and in Finland it was $80 \%{ }^{(15)}$ As in most of studies, females reported more frequently brushed their teeth than males, especially in older age groups because females are consistently more likely to brush frequently than males. This was in accordance with many studies. ${ }^{(13-19)}$

The mean plaque score for the total sample was 0.9 . There was a significant difference between the three ages. This finding was in agreement with other studies carried out in developing and developed countries. ${ }^{(20-23)}$ Females reported less mean plaque score than males with statistical significant difference because females care much about their looking and the amount of plaque is influenced by the person's oral hygiene and by various plaque retention factors. This was in accordance with other studies. $^{(20,24,25)}$

The mean gingival score was 0.52 for the total sample and it increased with age, because tooth brushing is associated with grouping and personal hygiene. These results came in agreement with those of other studies. $^{(26-28)}$

This study showed that the gingival health in females was better than males with statistical significant difference, because females care much about their looking and they brush more frequently than males. ${ }^{(14,29,30)}$ This confirmed the finding of other studies carried out in developing countries that females reported better periodontal conditions than males, ${ }^{(31-35)}$ and many studies in developed countries. ${ }^{(27,36-38)}$

\section{CONCLUSION}

Gingival and periodontal diseases are indirectly related to the exposure of bacterial plaque for long time which calls for integrated, coordinated planning of preventive and treatment services as an urgent priority.

\section{REFERENCES}

1. Pilot T, Barmes DE, Ieclerq MH, McCo- mbio B, Sardo Infirri J. Periodontal conditions in adolescents 15-19 years of age. Community Dent Oral Epidemiol. 1987; 15: 336-338.

2. Hagoson A, Koch G, Rylander H. Periodontitis in children and adolescents. Swed Dent J. 1981; 5: 91-103.

3. Khamrco TY, Al-Salman KhA. Dental health status among $4^{\text {th }}-8^{\text {th }}$ school children in the center of Mosul. Iraqi Dent J. 1998; 23: 77-88.

4. Murray JJ. Prevention of Dental Diseases. $2^{\text {nd }}$ ed. Oxford University Press. Oxford. 1989; Pp: 7-15.

5. Ramfjord SP. The periodontal status of boys 11-17 years old in Bombay. India J Periodontol. 1961; 32: 237-298.

6. Green JC, Suomi JD. Epidemiology and public health aspects of caries and periodontal disease. J Dent Res. 1977; 56(Sp Iss): 20-26.

7. Barmes DE. Oral health status of children, an international perspective. J Canad Dent Assoc. 1979; 12: 651-658.

8. World Health Organization. Report on Regional Training Workshop for Trainers on Atraumatic Restorative Treatment (ART). WHO Regional Office for the Eastern Mediterranean Alexandria, Egypt, 1996.

9. World Health Organization. Epidemiology, Etiology and the Prevention of Periodontal disease. WHO technical report series No. 621, World Health Organization, Geneva, Switzerland, 1978.

10. Silness J, Löe H. Periodontal disease in pregnancy-II correlation between oral hygiene and PD condition. Acta Odontal Scand. 1964; 22: 121-135.

11. Löe H, Silness J. Periodontal disease in pregnancy-I prevalence and severity. Acta Odontal Scand. 1963; 21: 533-551.

12. Khamrco TY, Makani LA. Oral and dental health status in Sada and Bahwiza villages. Iraqi Dent J. 1997; 20: 3-23.

13. Al-Alousi W, Al-Sayyab M. Plaque, gingival condition and brushing behavior in 15-years old Iraqi school children in the central region of Iraq. Iraqi Dent $J$. 1996; 18: 127-136.

14. Honkala E, Freeman R. Oral hygiene behavior and operiodontal status in European adolescents: An overview. Community Dent Oral Epidemiol. 1988; 16(4): 194-198. 
15. Honkala E, Kannas L, Rise J. Oral health habits of school children in 11 European countries. Int Dent J. 1990; 40(4): 211217.

16. Jensen K. Dental care practices and socioeconomic status in Denmark. Community Dent Oral Epidemiol. 1974; 2: 273 281.

17. Honkala E, Rimpela M, Pasanen M. Trends in the development of oral hygiene habits in Finnish adolescents from 1977 to 1981. Community Dent Oral Epidemiol. 1984; 12(2): 72-77.

18. Oliver RC, Brown LJ, Löe H. Periodontal disease in the United States population. J Periodontol. 1998; 69(2): 269-278.

19. Ambjornsen E. Remaining teeth, periodontal condition, oral hygiene and tooth cleaning habits in dentate old age subjects. J Clin Periodontol. 1986; 13(6): 583589.

20. Schou L. Oral health promotion at work sites. Int Dent J. 1989; 39: 122-128.

21. Griffiths G. Periodontal disease and malocclusion in 11 to 12 years old school children in South Wales MScD thesis. University of Wales. 1984.

22. Athanassouli T, Kolest KH, Mami H, Panagopubs $H$. Oral health status of adult population in Athens, Greece. Community Dent Oral Epidemiol. 1990; 18(2): 8284.

23. Now Jack R, Ainoma J, Suomi J, Kingman A, Driscoll W, Boown L. Improved periodontal status through self assessment: A 2 year longitudinal study in teenagers. J Clin Periodontol. 1995; 22(8): 603-608.

24. Abdal AK, Khamrco TY. Oral and dental health status in Sharkhan village. $J$ Coll Dent. 2000; 6: 150-156.

25. Health Education Council. The scientific basis of dental health education. Braz Dent J. 1979; 16: 51-54.

26. Makani LA. Evaluation of trails of dental health education in improving gingival health. MSc thesis. College of Dentistry. University of Mosul. 1998.

27. Sutcliffe P. A longitudinal study of ging- ivitis and puberty. J Dent Res. 1972; 7 : 52-58.

28. Kalliop Murtammaa H. Determinant of self assessed gingival health among adolescents. Acta Odontal Scand. 1997; 55: 106-110.

29. Chen M, Andersen R, Barmes M, Ieclereq M, Lyttle C. Comparing oral health care system. A Second International Collaborative Study. World Health Organization, Geneva. 1997.

30. Al-Dahan Z, Al-Dean L. Gingival health status among children and teenagers in Fingan village, Baghdad. Iraqi Dent $J$. 1998; 23: 97-107.

31. Wearhaug J. Prevalence of dental disease in Ceylon, association with age, sex, oral hygiene and periodontal condition. Acta Odontal Scand. 1967; 22: 121-135.

32. Al-Sayyab M. Oral health status among 15 years old school children in the central region of Iraq. MSc thesis. College of Dentistry. University of Baghdad. 1989.

33. Al-Sayyab M, Al-Alousi W, Al-Dujaili D. Periodontal treatment needs among 15 years old Iraqi school children in the city of Baghdad. Accepted for publication in J Coll Dent. 1991.

34. Al-Beiruti N, Tayfour MT, Poulos W. Oral health status of students in Syrian Arab Republic. East Mediterr Health J. 1999; 23: 304-310.

35. Ghali RF. Oral health status and treatment needs among students of Baghdad University. MSc thesis. College of Dentistry. University of Baghdad. 1989.

36. Douglass W, Gillings D, Sollecto W, Gammon M. National trends in the prevalence and severity of the periodontal disease. J Am Dent Assoc. 1983; 107: 403412.

37. Hansen BF, Gjermo P, Bergwitz-Larsen KR. Periodontal bone loss in 15 years old Norwegians. J Clin Periodontol. 1984; 11: 125-131.

38. Todd JE. Children dental health in England and Wales. HMSO. London. 1973; Pp: 22-31. 